\title{
Business internet use in small, family owned and managed hotels in Scotland
}

\section{Jo Fyfe, Richard Bent and Claire Seaman*}

\author{
Queen Margaret University, \\ Edinburgh, EH21 6UU, Scotland \\ Email: jofyfe43@gmail.com \\ Email: rbent@qmu.ac.uk \\ Email: cseaman@qmu.ac.uk \\ *Corresponding author
}

\begin{abstract}
Tourism and hospitality are strategic priorities for the Scottish Government but often highly dependent on small, family owned and managed hotels. This exploratory study is designed to initiate dialogue and to explore the operating environment and perceived business support needs in the ever-more complex and dynamic e-environment. The internet has altered the manner in which the hospitality industry operates; offering global marketing opportunities, open-source review sites and the opportunity to sell directly to the consumer. Results indicate that the positive aspects of the internet were perceived to outweigh the disadvantages but challenges were identified around the effective management of online resources and global reputation. There are areas in Scotland, and indeed much of the world, that draw tourists yet are not sufficiently populous to host hotel chains or even specialist boutique hotels. Tourists are often drawn to relatively undeveloped areas, creating a challenge for learning within small independent hotels.
\end{abstract}

Keywords: small business; family business; hotels; tourism; internet use; marketing; Scotland.

Reference to this paper should be made as follows: Fyfe, J., Bent, R. and Seaman, C. (2020) 'Business internet use in small, family owned and managed hotels in Scotland', Int. J. Business and Globalisation, Vol. 24, No. 2, pp.256-274.

Biographical notes: Jo Fyfe is a hotelier and graduate from the Queen Margaret University in Edinburgh and has worked a range of hospitality jobs in Australia, New Zealand and Scotland, but her heart lies in the family business on the West Coast of Scotland. She noted how the family business was changing due to the affect of OTAs and the internet. She saw that the internet and OTAs have changed the market and type of client in the hotel industry and greatly increased numbers of bookings.

Richard Bent specialises in small business research at the Queen Margaret University in Edinburgh, UK. His work includes a focus on the development and decline of the traditional high street, alongside the family dimension of SME research.

Claire Seaman specialises in family business research, focussing in particular on the dual strategies employed by family businesses to balance the family and business. This consideration of strategy includes the development of successful approaches to succession, the role of networks and knowledge sharing in family firms and education for the next generation. 


\section{Introduction}

Tourism is a key economic sector for Scotland (Scottish Government, 2015) but despite its acknowledged economic importance the industry remains one that is highly dependent on small, family owned and managed businesses (Getz and Carlson, 2000; Peters and Buhalis, 2004). The importance of family businesses in the Scottish economy has similarly been noted (GGiS), both in terms of their overall importance and in terms of their increasingly disproportionate importance in rural economies. Dana and Ramadani (2015) highlight the impact of the small business and family businesses specifically on the generation of jobs and national economies. The research conducted here focuses on one of the towns at the 'outer-reach' of the chain hotels market in Scotland. The family owned and managed businesses that form the focus are often in direct geographic competition with chain hotels but in practice operate in an environment where awareness and exposure to the digital strategies of the major accommodation and food service players within the tourism industry may be limited. This is perhaps of especial importance given the general decline in numbers of businesses offering accommodation in Scotland, which has fallen from 2,765 in 2010 to 2090 in 2015 (Scottish Government, 2015). Conversely, airline access and the consumers who are being encouraged to visit Scotland by destination marketers has never been greater, with Edinburgh Airport now offering direct flights to 133 countries, including direct services to China amongst other recent additions (Edinburgh Airport, https://www.edinburghairport.com/).

Within Scottish tourism, many of the small hotels are family owned and run and the importance of appropriate support that balances the needs of the business with the additional, family dimension has been noted (GGiS); a facet also likely to apply to their approach to the internet. As an initial stage, therefore, the current research considers the extent to which smaller, family owned hotels in Scotland engage with the internet. The family dimension has not formed a core part of research that looks at internet engagement. Focussed research that considers the particular challenges of this group of businesses and the strategies that might be employed at local, national and international level to facilitate constructive strategic development forms, therefore, part of the conclusions from this paper. Further, there is potential for the family to be one key defining factor in the business identity, raising questions about the development of family-business identity online and the extent to which small family run hotels perceive this as an opportunity or a challenge is explored and highlighted as an area for future research with a focus on the intersection between family business and the digital environment. The importance of tourism and hospitality for the economy of Scotland and the strong links to digital strategy are a focus within current policy. Notably, the Tourism Development Framework (Tourism Scotland 20:20) focuses upon digital connectivity under theme 1 and notes:

\footnotetext{
"The quality of the customer journey is increasingly dependent on the availability of digital information. In most instances, the customer journey will start with website searches at the planning stage, based at home."
}

Gerguri-Rashiti et al. (2015) discuss and investigate the importance of communication technologies (ICT) and innovation activities on firm performance. They also highlight the rapid growth and changes that have and continue to occur in this field. As a key consumer facing marketing and distribution channel for this sector the importance of technological impact and continual change cannot be understated in a competitive 
scenario. By acknowledging the overlap between academic hospitality research, work that considers the small, family business dimension and entrepreneurship research this paper aims to offer a unique insight into a vital but complex group of businesses. Within entrepreneurship research, much is written about the logics that drive individuals to be a small business owner and one driver is clearly the understanding that a small business represents the best employment opportunity and/or lifestyle available for an individual. For individuals within a family business, therefore, it is important to note that the family and/or business dynamic may be far more important than any individual's aspiration to be a professional hotelier.

\section{Literature review}

The internet continues to shape the future, impacting and changing industries (Kim et al., 2006; Phelan et al., 2011; Shuai and Wu, 2011) and influencing the environment in which traditional smaller family owned and managed hotels operate. With the rapid development of information and communication technologies, the observation has been reported that business intelligence has evolved form the analysis of traditionally structured business transaction data to the study of unstructured, real-time data driven by e-commerce and social media (Chen et al., 2012). The impact of these developments on small family owned and managed hotels has been considerable and a literature has developed in this area that focuses upon four key themes:

- $\quad$ marketing and advertising

- customer empowerment

- distribution channels

- website optimisation.

According to Heung (2003) and Phelan et al. (2011) the hospitality industry is suited to the internet. This is due to the highly tangible nature of the hospitality product (allied to the less tangible service element). If a bedroom is not sold then this is deemed as lost revenue (Kim et al., 2006; Litvin et al., 2008; Rong et al., 2009; Castillo-Manzano and Lopez-Valpuesta, 2010). Berne et al. (2012) adds that the internet has enabled hotels to work more efficiently and effectively which can increase hotels' performance and profitability whilst in parallel Etemad et al. (2010) note the integrality of the internet within international business. Where a small, family run hotel interacts with the internet, however, there are a number of distinct aspects that may influence the online dynamic.

In the Scottish context, the importance of international clients cannot be understated. Scotland itself has a long history of net migration and invention that now stimulates (in certain countries such as the USA) a desire to visit and experience the 'home' country of Scotland. Equally, the history of Scotland whether driven by the physical home of sports such as golf or by the often somewhat fictionalised stories associated with productions such as Braveheart, Outlander, Harry Potter, the Rebus books of Ian Rankin and indeed Trainspotting, attracts different but committed visitors and forms a recent part of marketing campaigns by Visit Scotland in 2017-2018. These aspects, alongside the fall in the value of Sterling, have created a circumstance where Scotland attracts 14.1 million visitors annually, equivalent to over two and a half annual visitors per head of population. 
Recent increases in visitor numbers to key attractions, such as Edinburgh Castle and the National Museum of Scotland, have seen visits to each rise to over 2 million visitors annually with a consistent upwards trajectory in visitor numbers. The importances of these iconic attractions on the ground are key to driving the arrival of tourists who then visit a variety of dispersed attractions and locations.

\subsection{Marketing and advertising}

Armstrong et al. (2009) proposed that marketing is crucial to the success of an organisation, and is a cycle that starts and finishes with the consumer (Walters, 1977; Kerin et al., 2009). Without customers a hotel will not succeed and the business will fail if the marketing department focuses more on the business objectives and not on the customer's wants and needs (Williams, 2006). With customers being the main priority of the hospitality industry, hotels must understand and satisfy their customers need and wants effectively in order to succeed and ensure long-term survival (Cizmar and Weber, 2000; Mawson, 2000). The advent of the internet has allowed hotels to target their customers more precisely (Buhalis and Licata, 2002; Chathoth, 2007) as hotels can provide up to date information directly to their customers (Wang and Wang, 2009). This can enabled hotels to be able to tailor their product and services more precisely to their customers, to satisfy their needs and wants. However, Martin (2007, p.742) adds "understanding tourist behaviour is difficult because many variables affect the decisions." This may be due to the internet changing consumers purchasing behaviours (Bentley, 2011; Cacia et al., 2011) which has resulted in an increase in customer empowerment (Cacia et al., 2011). Kotler and Armstrong (2011) advocate that businesses must attract new customers by offering value and retain existing customers through fulfilling their wants and needs. The internet has allowed the marketing and advertising of a hotel to reach a more global audience ( $\mathrm{Wu}$ et al., 2008), thus showing that the internet has enable hotels to market more globally and target more effectively. This has benefitted hotels as customers are the foundation point of a hotel's success. On the reverse side (in relation to small independent hotels), the growth of the homogenous value and consistency driven hotel formats has disrupted the traditional hotel-consumer dialogue. The uniqueness and variety of the independent, family run hotel sector may be their USP, but it can also ensure criticism is felt more keenly. Where the response to what historically might have been a minor or even a major service failure, unnoticed by future guests, is now online and visible to the world, with the associated capacity for reputational damage increases and may compound the problem.

\subsection{Customer empowerment}

Erdogmus and Çiçek (2011) suggest that the online consumer buying market is developing quickly in a response to a rapidly changing consumer lifestyle. People have become more 'time poor' and are more focused on ways to save time and money (Heung, 2003). Wang and Wang (2009) propose that the internet has led to a change in the way consumers and hotels interact with one another, as the increased use in the internet has changed consumers' behaviour patterns and perceptions of products and services (Bentley, 2011; Cacia et al., 2011), and has "contributed to an unprecedented customer empowerment" [Cacia et al., (2011), p.145]. Another reason for this increase in buying power is due to the internet's ability to provide more choices and up to date information 
(Kucuk and Krishnamurth, 2007). Therefore consumers have the power and opportunity to find a hotel most fitting to their needs and income. Jobber and Fahy (2006, p.297) recommends that a vital part of marketing success is deciding the best distribution channel. Wong and Law (2005) propose that the key to survival in the current competitive environment is reducing distribution cost through new distribution channels. The internet has exposed new distribution channels and has opened opportunities for hotels to trade (Wynne et al., 2000: Kim et al., 2006; Shuai and Wu, 2011). Where technology has allowed consumers to be empowered and take on the review of the traditional 'hotel inspector', the power of the e-environment is increased exponentially.

\subsection{Distribution channel}

According to O'Connor (2008b, p.140) a distribution channel is "the manner in which companies bring their product to the marketplace" and offers a suitable way for businesses to sell to the customer. O'Connor (2008a) suggests that the main purpose of distribution channels is to provide information to the customer. Castillo-Manzano and López-Valpuesta (2010) proposes that online distribution channels are the most applicable place to sell hospitality products, due to their intangibility and can react quickly to the shape of the market required by the industry and the consumers (Berne et al., 2012). The advent of the internet has generated growth in electronic distribution channels (Tso and Law, 2005; Morosan and Jeong, 2008; Pizam, 2010) as consumers substituted traditional channels with online e-DC's due to their convenience and up to date information (Tse, 2003; O'Connor and Murphy, 2004; Forrester, 2008). The use of electronic distribution channel has led to hotel services being more organised and efficient compared to when they used traditional methods (Carroll and Siguaw, 2003). Interestingly, it could be argued that in the case of hotels the distribution channels are notably different; in that part of the main distribution channels distribute not just the marketing information but the physical customers themselves. The importance of aircraft routes (i.e., the new Edinburgh-China flight routes) as a driver of potential customers as an indirect distribution channel is an under-explored area of research but one that ties in to the potential consumer market for suitable local accommodation.

An overlapping area of marketing and advertising and distribution channels is the hotels website. The increased amount of online competition (Cizmar and Weber, 2000; Wang and Wang, 2009), has resulted in a need to create a competitive advantage (Kim et al., 2006). Wang and Qualls (2007) and Phelan et al. (2011) suggest developing a competitive advantage in order to win customers. In 2003 Tse (2003) recommend that this can be done through the internet as it is a more dominant and cheaper channel to sell through. More recently, the costs of maintaining and developing a suitable online presence has increased in time and direct costs contributions and this in part may be the challenge for smaller, family run businesses. Website development is a specialist topic; done well it requires expertise and usually funding. Although a few smaller, family hotels may have the expertise within their immediate network and/or the resources to pay for outside help, for many this presents a very real challenge and a limiting factor in their ability to compete directly with the commercial hotel chains. 


\subsection{Website optimisation}

The challenges of website optimisation are in many ways similar to those of distribution channels, in that the topic represents an expensive essential for most businesses. With the increase in online competition and globalisation there is little to differentiate between hotels, thus the need to be perceived as unique in terms of provision and service (Hassanien, 2010). Wong and Law (2005), Morosan and Jeong (2008) and Shuai and Wu (2011) suggest that the hotels website is the most appropriate way of selling the hotels intangible assets as it allows the customer to see the hotel before staying. Hassanien et al. (2010) adds that it is the intangible parts of the hotel which are vital to create a competitive advantage. Carter and Jones-Evans (2000, p.285) define competitive advantage as "an advantage that is valued by customers and which distinguishes the business from its competitors." This may be the way that small, family run hotels can differentiate themselves from competition.

Large company-owned hotels often have the opportunity to out do independent hotels through their marketing skills as they may have more resources and finance. However, small businesses can react faster to opportunities compared to large hotels, but may not have the resources to make new opportunities happen (Carter and Jones-Evans, 2000). Therefore, Shuai and $\mathrm{Wu}$ (2011) propose that if an independent hotel establishes a well designed website, this will create an effective marketing and advertising platform reaching a more global audience (Au Yeung and Law, 2004). Once set up it is imperative that it should be kept up to date (Chung and Law, 2003; Baloglu and Pekcan, 2004). As Salerno (2007) points out that the internet has been a vital search tool in finding a hotel online and now customers are able to book a room online twenty four hours a day, seven days a week (Phelan et al., 2011). Also this has led to large amounts of information which allows customers to explore other options, compare where to book a similar room at a cheaper price and ultimately choose the right hotel for them (Buhalis and Licata, 2002; Tse, 2003; Tso and Law, 2005; Kim et al., 2006).

In addition, to the oft cited resource availability issues amongst the independent sector, Veland et al. (2014) highlighted in the technology acceptance model (TAM) the multiplicity of factors that can both influence (e.g., trust), encourage (e.g., perceived usefulness) and detract (e.g., ease of use) potential users from uptake and utilisation of social media channels, perhaps even to their detriment.

The authors reflecting on the myriad of issues that may both impinge and provide opportunities to the independent operator, also holistically recognise that their primary role is as a 'hotelier' rather than a social media/internet practitioner. It is perhaps worth noting this point, both in terms of the methodological direction of this type of study but also in the expectations of the respondents as to what their professional roles might be expected to encompass. The motivations that drove individuals and their families to run hotels when the internet was in its infancy may well not link entirely smoothly with the skill and interests useful in the digital age. However, we would agree with the assertions made by Ramadani et al. (2017) that businesses will benefit from 'knowledge spillovers' from a variety of sources and that this can both be incentive and encouraged further toward improving business performance. 


\section{Modelling business critical internet applications}

From the literature, it becomes evident that the four business-critical areas are interlinked and affect each other in multiple and dynamic ways. Therefore a conceptual model was constructed (diagram 1) to illustrate the connection between each topic. This links to the causality effect, described by Janes (2001) as a cycle where by each stage affects the next stage and where between stages there has to be cause and effect. In relation to this research the internet has affected marketing and advertising, therefore changing and introducing distribution channels and in turn altered consumer buying behaviours and reservation methods. Without the use of online marketing and advertising or online distribution channels, consumers may be less likely to book using traditional methods as people become increasingly 'time poor'.

Figure 1 Modelling business critical internet applications

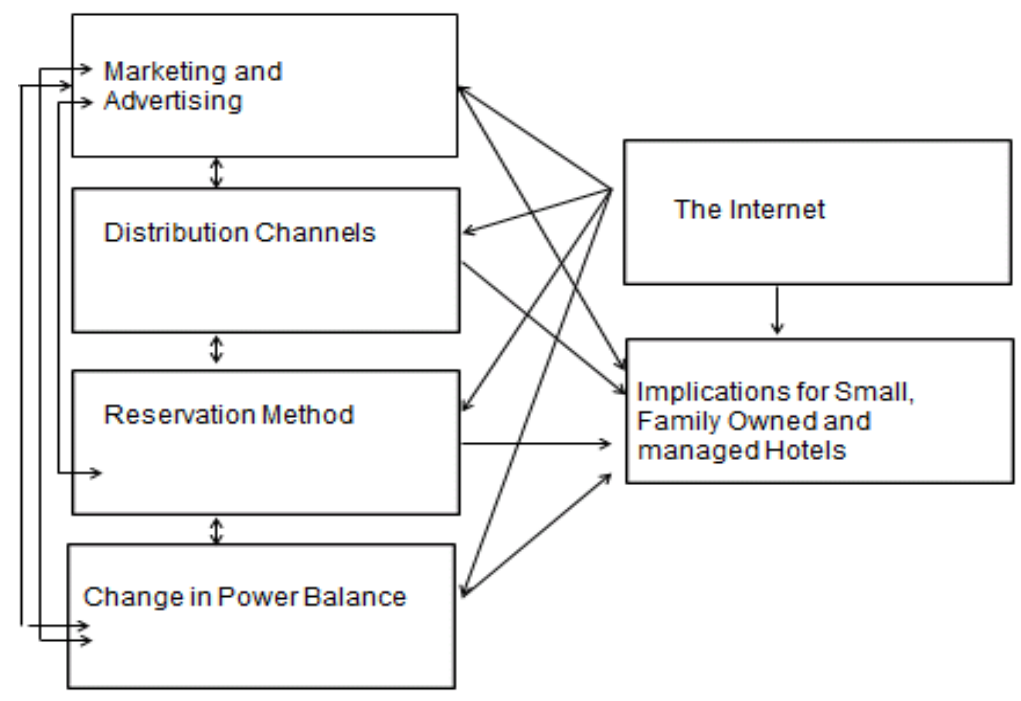

One key advantage of the internet/e-environment was being able to potentially target and reach a wider or indeed more global audience. However, by focussing the direction of this paper on smaller, family owned and managed hotels an additional dimension is added that outlines what may be one of the key challenges. Drawing on research from the field of family business, an additional theme that emerges strongly is the concept of identity within smaller, family owned and managed businesses. In particular the intersection between the business and the family identity, which Shepherd and Haynie (2009) described as creating a meta-identity of the family-business, primarily where the family identity and the business identity are activated together, but to act in a way consistent with one concurrently requires actions inconsistent with the other. This description of conflict between the family and the business identity may be especially important where consumer empowerment sites such as Trip Advisor form the focus and, whilst acknowledging the wider impact of the developing internet on the business environment the importance of family business identify and its impact for the manner in which businesses engage with consumer empowerment sites offers an additional area for research. 


\section{$4 \quad$ Aims and objectives}

The main aim of this research project is to discover how the evolution of consumer empowerment websites has influenced family owned and managed hotels in Scotland. To achieve the aim, objectives were established:

- To explore how the growth of the internet has impacted upon the online presence of Scottish small family owned and managed hotels.

- $\quad$ To investigate the perceived impact of consumer empowerment websites amongst the owners of small, family owned and managed hotels.

- To identify the main fears and concerns that owners express, alongside the advantages and disadvantages consumer empowerment websites are perceived to offer their businesses

\section{Methodology}

The engagement of smaller, family owned and managed hotels with the internet in general and consumer empowerment websites in particular is an area where the conflation of family and business identity may be key. There is currently little research that focuses upon this topic, however and the study was therefore designed to be exploratory and to gain insight into this area (Zikmund, 1997). Collis and Hussey (2009) suggest that exploratory studies seldom give conclusions to problems but offer suggestions for future research and this describes very well the purpose of the current research. Developed from a social constructivist epistemology (Creswell, 2018), semi-structured interviews were used to explore the impact of consumer empowerment websites on smaller, family owned and managed hotels. The distinction between research described by Dana and Dumez (2015) as comprehensive and qualitative research has been discussed but within this debate agreement has been reached that the methods that fall within these approaches have an exploratory focus useful for highlighting key processes as a prelude to potential policy development, the development of support mechanisms and indeed to larger scale and primarily positivist studies.

In this study, definitions from Dix and Baird (1998), Baker et al. (2000) and Bardi (2007) are used, determining that a small hotel must have between 1-50 bedrooms. Twelve small family run hotels were identified, using the telephone directory listings to ensure that online presence was not a pre-requisite for inclusion. The key purpose of the research is to extract, explore and gain detailed understanding of the perceptions of independent hoteliers who fall within the broad definition of entrepreneurs. The appropriateness of qualitative or comprehensive methods for the exploration of entrepreneurial behaviour, highlighted by Dana and Dana (2005) and indeed for the development of deep understanding of those behaviours is a well-established approach (Dana and Dumez, 2015). The limitations of this study primarily derive, therefore, from the methodological approach. We acknowledge these limitations but highlight the 'business driven', prospecting nature of the current research which was developed from on-going contacts with hotel owners. Though limited in its generalisability, it has identified a range of issues and future challenges that we would recommend are worthy of a more quantitative and funded approach. 


\section{Results and discussion}

\subsection{Business identities}

Out of the 12 participants, eight were owners who self-identified as leading online matters within their business and the other four were senior family managers whose job was to manage the internet and online bookings. By using purposive sampling to target those within the business most directly engaged with the internet, the aim was to garner the most pertinent, recent experience and to explore the views of those most likely to be directly affected by online reviews. Within the results, therefore, owners will be referred to as $\mathrm{O} 1-\mathrm{O} 8$ and senior managers referred to as SM1-SM4.

\subsection{Interview themes}

\subsubsection{Impact of the internet on small, family owned hotels}

Heung (2003), Kim et al. (2006), Castillo-Manzano and López-Valpuesta (2010) and Phelan et al. (2011) all proposed that hotels are well matched to the internet due to their highly intangible nature, as a bedroom not sold is lost revenue. More than half of the respondents $(\mathrm{O} 2, \mathrm{O} 3, \mathrm{O} 4, \mathrm{O} 8, \mathrm{SM} 1, \mathrm{SM} 2$ and $\mathrm{SM} 3) 3$ agreed that the internet has led to an increased amount of business. This may be due to being able to target a more global audience. O3 (p.14: 17-18) strongly states that:

"With companies like Booking.com and Laterooms, we wouldn't be nearly as busy if it wasn't for companies like them."

SM1 (p.39:16) adds that:

"Without these internet bookings we would not be able to sell the rooms."

\subsection{Targeting customers}

Cizmar and Weber (2000), Mawson (2000) and Williams (2006) suggest that the success of the hotel is the hotels ability to satisfy the customer's demands. With the advent of the internet this has allowed hotels to target customers more precisely and directly (Buhalis and Licata, 2002; Chathoth, 2007; Wu et al., 2008). The majority of the respondents O1, O2, O5, O7, SM1, SM2 and SM3 four stated that the internet has helped to target their market more effectively. SM2 (p.44: 84-88) explains that the internet has allowed

"[The hotel to] have the customers that we really want, not just people walking in off the street."

O2 (p.11: 91-93) states that it is easier due to having

"Mailing lists that you can put out special offers. In the old days you had a business card and you hoped people would take a card."

However, Martin (2007, p.742) proposed that

"Understanding tourist behaviour is difficult because many variables affect the decisions."

Yet the minority of hotels agreed with the literature (O3, O4 and SM4)4, that there was not really a target market they were aiming to attract SM4 (p.52: 72-73) indicates that 
"[it is] debatable really, because nowadays I don't think you really target customers, what you have to do is price yourself as competitively as possible."

The increase in consumer power may have led customers having higher expectations even if this is conversely combined with a lower price. As the internet has enabled a more global audience this may have consequences that make it more difficult to target a global multi-cultural.

Morosan and Jeong (2008), Guest Centric (2011) and Ip et al. (2011) suggest that hotels need to use an assortment of distribution channels both traditionally and electronically so that hotels can sell their product and service successfully. This was advocated by $\mathrm{O} 1, \mathrm{O} 4, \mathrm{O} 5, \mathrm{O} 6, \mathrm{O} 8, \mathrm{SM} 1, \mathrm{SM} 2$ and SM3 five stating that they use mixed methods of advertising, there were a variety of reasons why hotels still use traditional methods, SM2 (p.43: 63) said the reason was

"Because we don't have to pay the commission if we get people in ourselves."

SM3 (p.48: 76-77) stated that

"Guide ratings and inspections are still important to a lot of people."

and $\mathrm{O} 8$ (p.37: 72) noted that

"There are still people who don't use the internet."

However, O6 (p.30: 60-61) still used both methods but noted that advertising in magazines and newspapers is an

"Increasingly it is just a waste of money."

O2 (p.12: 107-110) stated:

"If there was no internet then people would not know we are here and I wouldn't like to rely just on brochures, you definitely hit a larger medium of people, that is the whole point you are always looking for that, that golden street in some ways."

This shows an increased reliance on the internet and a substantial reduction in other media but arguably 'other' media has now become the 'social media' phenomenon. Prioritising and monitoring spend will, as previously, be the challenge for all players but small, family run hotels on limited resource budgets will have to increasingly managed their internet/social marketing strategy.

\subsection{The use of e-distribution channels}

Ma et al. (2003), Kim et al. (2006) and Phelan et al. (2011) suggest that the advances of the internet has changed the structure of the hospitality environment leading to modifying the way consumers and hotels interact, which may have changed consumers behavioural patterns and perceptions (Bentley, 2011; Cacia et al., 2011) and that consumers are looking for value for money. O'Connor and Murphy (2004), Morosan and Jeong (2008) and Guest Centric (2011) state that due to the recession this has positioned the hospitality industry in a weakening situation. As a consequence of this, hotels have to sell a large percentage of their rooms through commission-based distribution channels. The common theme for using online booking sites was because of the amount of bookings that they provide resulting in more business $(\mathrm{O} 1, \mathrm{O} 2, \mathrm{O} 4, \mathrm{O} 6, \mathrm{O} 8, \mathrm{SM} 2$ and SM4)3. O2 (p.10: 
49-50) states that the main reason for moving the hotel onto online booking sites was because

"They have a high prominence of people always searching again they are on the front pages of all the major search engines."

in which O8 (p.36: 53-57) adds that:

"It is the quantity of bookings that these sites can provide by using booking sites for example Booking.com and Laterooms [they give] smaller operators the opportunity to use their web presence and the brand of these companies and to place your business into a much larger world wide audience and catch business that would never come directly to your site."

In spite of this, there were various reasons why hotels moved onto booking sites, O5 and SM3 state that the reason for moving onto these booking sites was because O5 (p27: 39) states

"It's the progression of the times, computers are the future."

and SM3 (p.47: 57) adds that

"Because it was the trend everybody was doing it so they needed to follow the trend."

When asked about paying the commission and reaching higher occupancy levels than not paying the commission and having lower occupancy levels the general consents was that it was better to pay the commission $(\mathrm{O} 1, \mathrm{O} 2, \mathrm{O} 3, \mathrm{O} 4, \mathrm{O} 5, \mathrm{O} 6, \mathrm{O} 8, \mathrm{SM} 1, \mathrm{SM} 2, \mathrm{SM} 3$ and SM4)6 as the money can be generated from other parts of the hotel, O2 (p.10: 64) pointed out the integrality of the business model:

"Let a room because you cannot get it back it is dead."

However $\mathrm{O} 7$ (p.33: 46-47) stated that

"The bigger hotels can get back the money by doing other things for example their drinks prices."

Although the commission that these e-DCs are asking for is just enough SM3 (p.49: 109-112):

"At the minute the percentage [online booking companies are] taking is fine, but if they start to get greedy and put that up then that would be a concern. On our own website if you book through that it goes through booking.com so then we are only paying $3 \%$ commission, they are helpful for small businesses that way."

This shows that SHIs are using booking sites, the most common being Booking.com and Laterooms to gain web presence and as a cheaper way to market and advertise the hotel. If it was not for these booking sites then some small family run hotels would be more difficult for consumers to find. In addition, O1, O2, O6, O8, SM1, SM2 and SM4 (7) all mentioned that the internet had helped them throughout the recession this was due to O2 (p.11: 73-78) pointing out:

"You can put everything online, special offers. Lot['s] of people can look. You can keep them on your webpage. On our website we have a booking button on every page so you don't have to go back, to make it easier as possible. The easier the better, and then you can look at Google analytics and see how long 
people are staying on your site, so you know if you get over two minutes then you are usually going to end up with a booking."

\subsection{Websites}

Wong and Law (2005), Morosan and Jeong (2008) and Rong et al. (2009) suggest that hotels could create a competitive advantage through the hotels website and this approach is to persuade customers to book through the website rather than commission-based distribution channels. However, how can small family owned and managed hotels compete with large e-DCs for example booking.com and laterooms to encourage customers to book with the hotels website rather than these commission-based channels. Customers may only know about their hotel through these e-DCs. The most common theme that arose when asked how small, family run hotels can differentiate themselves against competition is using the hotels unique features that hotels as their unique selling point (USP) shown on their websites (O2, O4, O6 and SM2)8. SM2 (p.44: 96-97) says

"By having quirky unique qualities about the hotel [the hotel can differentiate itself as] everyone is looking for something unique."

Law and Hsu (2005) suggest that the success of the hotels websites is due to the technology used and the appearance of the site, however as respondents show that it is hard to gain a web presence. Training and knowledge of how to differentiate and promote is a future challenge for all small family owned and managed hotels.

\subsection{Fears or concerns}

There was a gap in the literature regarding the fears and concerns of small, family run hotel owners/manager would experience in regard to the use of the internet. This was identified as the main gap in the literature and reason for further research. The main fear that the internet brings to the owners and senior managers towards small, family run hotels is larger companies (O2, O4, O6 and O7)9, O4 (p.25: 108-110) states that

"Larger companies are monopolizing room rates, people are comparing prices with Travel Lodge that are quite nearby, as they have the power to advertise."

O7 (p.32: 28-29) adds that

"Big businesses have the advantage on the financial side, they can afford to make it cheaper something that small businesses can afford to do."

However O3 (p.16: 74-80) spoke about the internet in a more positive way about larger businesses:

"I think that it gives us a better opportunity to compete in a market with Premier Inn or Holiday Inn or places like that, because they are all recognized names and they are worldwide brands as it were. But with the internet it is a more level playing field, because small business, like there are a lot of companies that will do everything they can do to try and set you up with various packages or various incentives like ahh, Google add words, um just pick a few key words and they will do everything that they can do to make sure that you appear on the first result on a webpage."

Wu et al. (2008) and Wang and Wang (2009) all note that the development of the internet this has lead to an escalation in online competition. $\mathrm{O} 4$ and $\mathrm{O} 8$ stated that competition 
was a main disadvantage of the internet in the form of the difficulty to gain a web presence. $\mathrm{O} 8$ (p.35:25-34) states that:

"It is increasingly difficult to establish a large web presence, due to larger companies like Hilton having massive budgets. A large web presence can only be achieved by using a large budget to buy the expertise in web marketing and to pay for web advertising. A small company could not fund this economic because even if they are successful in creating the business and turnover there would be insufficient capacity in sales outlets, for example room sales and food and beverage sales to fund the large web presence. Only large companies with many outlets have the revenue to potential fund these large marketing campaigns, they have the potential to generate the revenue and profit from their collective sales potential. Smaller or single unit operations have to use not only their websites and web presence, but also other sites either to advertise or receive bookings."

O4 (p22: 29-30) also explained that

"It's difficult to make your website stand out from everybody else's."

Another disadvantage mentioned was personal knowledge of the internet. The majority (O4, O5, O7, SM2, SM3 and SM4) manages their own web page and bookings (Appendix 10); they may lack knowledge in achieving the most out of their resources. O6 (p.29: 27-29) mentions that

"You are only as good as your internet ability, if you're not computer literate or don't have anyone online that can help you then you can be side lined."

O5 and O8 (11) agree that the need for knowledge is important. The majority of hotels who do their own bookings have fewer bedrooms than the others with Hotel 11 the exception. The work suggests that those Hotels who do their own websites and online bookings as well are achieving the most.

\subsection{Consumer empowerment sites}

A recurring theme evidenced early in the majority of interviews was the significance of review sites $(\mathrm{O} 2, \mathrm{O} 3, \mathrm{O} 4, \mathrm{O} 5, \mathrm{O} 8, \mathrm{SM} 2$ and $\mathrm{SM} 3) 1$. This topic may have had a positive or negative impact on the interview. SM2 (p.43: 35-39) states [it is]

"The way that anyone can just write a review not having stayed in the hotel, whereas booking.com you have to have stayed at the hotel."

O4 (p.23: 37-41) adds that:

"These review sites you do get one or two people whether they are genuine or not...they leave you these negative reviews on Trip Advisor and you don't know if they are genuine, [or] it could be a competitor."

Even though the respondents spoke negatively about review sites, the common response of the internet was that the positives outweigh the negative $(\mathrm{O} 1, \mathrm{O} 2, \mathrm{O} 4, \mathrm{O} 5, \mathrm{O} 6, \mathrm{O} 8$, SM1, SM2, SM3 and SM4). The language used in commentary about the development of consumer empowerment sites is interesting, however, as it seems to reflect the merged 'family and business' identity referred to in the literature.

The majority of the interviewees commented that the negative comments on review sites such as Trip Advisor were the biggest disadvantage of the internet; O3 (p.16: 56-58) explains that it is the negative comments online in which are the main disadvantage as 
"People just display a lot more cowardice in negative comments, because they can just sit behind the key board rather than speak to people face to face about it."

O2 (p.9: 27) notes that

"If you get a bad review then it is very damaging."

O5 (p.26: 24) adds that

"Trip Advisor is a disadvantage as you can't control it."

however O8 (p.36: 40-42) suggests that

"Management have to pay attention to these comments to look for patterns or

repeated complaints so that they can be addressed and hopefully rectified."

The key issue here was 'management' and perhaps 'how to' manage online reviews.

\section{Conclusions}

The research showed that the main change the internet created was the way smaller family owned hotels market and advertises their product combined with the emergence of the e-DCs. Two key issues stand out, Firstly the introduction of these e-DCs has enabled small family owned and managed hotels to use the e-DCs web presence to advertise, as it has become increasingly difficult for small family owned and managed hotels to gain a web presence with larger companies having a larger marketing budget. Secondly the internet has given small and family run hotels the opportunity to market to a more global audience thus targeting people who did not previously know about the hotel therefore increasing room occupancy. Therefore, the challenge is to maximise the positive opportunities and negate where possible the advantages of the large hotels.

While small family owned and managed hotels can now market and advertise to a more global market, a minority of respondents suggested that there is not a market to target; this may have been a knowledge issue or a difficulty in identifying a tangible grouping? Developments in technology, the high prominence of booking sites and reach were the reason for small and family run hotels. The majority of respondents use booking sites as a main source of generating business. It may be suggested that small, family run hotels are becoming more dependent on them; however some research suggests that the effects of the earlier recession and the consumers search for 'value for money' may also be a factor. All the sampled small family run hotels have their own website, however it is becoming increasingly difficult to gain a large web presence and compete with large company owned hotels. By showing the small family run hotels unique features on their websites, this can hopefully differentiate between competitions.

The main fears and concerns of the respondents were that larger companies can monopolise and to an extent dictate room rates, as they are able to generate income from other departments. These larger companies have larger budgets for marketing and advertising therefore gaining a larger web presence. Another fear is lack of knowledge within small, family run hotels in how to gain a web-based skill vary from person to person. The main advantage of the internet is the global reach and allows small, family run hotels to reach more customers than previous. However, disadvantages of the internet are the challenge to gain a web presence and compete with these larger hotels. 
Another disadvantage is review sites such as Trip Advisor. A bad review about a small, family run hotel have more of a negative impact on the smaller individual hotel than a large company owned hotel. The reason for this may be due to large company owned hotels having a well established brand name therefore a negative comment may not on their own damage their reputation, whereas it may damage small, family run hotel's reputation as they do not have a large compensatory brand identity. Consequently some small, family run hotels operators need to develop or be assisted in developing an strategy for managing and mitigating/enhancing positive or negative reviews. Importantly, the need to act instead of ignore as a tactic is worthy of further study and potential testing.

The primary research shows that negative comments on review sites can have a negative impact on family owned and managed businesses if not handled correctly. Trip Advisor is undergoing changes in how customers can post comments about hotels; however there is limited academic literature around this issue. This is likely to have been due to the sudden development and emergence of this area. Further research could stem from this and explore how customers choices are affected by the comments left on review sites and how these reviews impact small family run hotels. The research also revealed that owners and managers require basic computer literacy skills and in many cases this knowledge seemed to be lacking, this was shown by O5 (p.28: 80-782) pointing out:

\footnotetext{
"I can use a computer, but I'm not competent, my age group. That would be my biggest concern; because you cannot afford to pay a dozen people $£ 100$ a year to do what one person should be able to competently do."
}

The majority of owners and managers interviewed managed their own online bookings and website; however most were within the 40-60 age range and highlighted the need for individuals to develop their internet skills. It may be of great importance for government bodies for example Visit Scotland to pay attention to this area. As tourism is one of a countries source of income, attracting tourist to Scotland is vital. Visit Scotland's (2005, p.2) ten year projection of Scottish Tourism states that "visitors to Scotland come for an experience that is rooted in our hills and glens, our castles and towns, our history, our culture, our way of life and our people" and further add that tourists who visit Scotland "are touched by the knowledge of being somewhere distinctive and special." For that reason it is imperative that small family run hotels do not lose but use their identity when facing better resourced branded hotels. For Example, Travel Lodge and Premier Inn have a large marketing budget and can afford to gain a larger web presence than small, family run hotels coupled with the ability to structure the required commission fees in a more strategic and economic manner.

The implications for future research are extensive. We conclude that it is vital that business educators who engage with hospitality businesses not only show an interest in how the internet is affecting small family run hotels but also assist in the development of appropriate training and skills development. With this increased knowledge this could enable the owners and managers of small family run hotels to gain a greater web presence with the resources and budget that they have and also increase confidence to deal with reviews. Importantly, also, this training should not be viewed as a 'one off' option but rather as an on-going aspect of business development that reflects the rapidly changing online world both in the UK and in countries such as China where online engagement with potential or actual tourist is under-developed but increasingly important. There are also a number of much wider, societal imperatives that need to be developed and brought 
together as a strategic approach by agencies and governments, including ongoing engagement between the digital strategy for Scotland and the tourism/destination marketing strategies. Additionally, the health of an independent hospitality sector in Scotland is important as it gives diverse consumers a range of options whilst accommodating tourism in rural areas that often do not support the business models adopted by major hotel chains.

A resilient and healthy tourism sector in Scotland and indeed in many parts of the world is in part dependent on the small family run hotels who are key to future innovation opportunities and often more 'authentic' experiences. Both contribute directly to tourism as a key economic priority sector for Scotland with spending by tourism generated around $£ 12$ billion in direct revenue in 2017 (Scottish Government, 2017).

\section{References}

Armstrong, G., Kotler, P., Harker, M. and Brennan, R. (2009) Marketing an Introduction, Pearson Education Ltd, England.

$\mathrm{Au}$ Yeung, T. and Law, R. (2004) 'Extending the modified heuristic usability evaluation technique to chain and independent hotel websites', International Journal of Hospitality Management, Vol. 23, No. 4, pp.307-313.

Baker, S., Huyton, J. and Bradley, P. (2000) Principles of Hotel Front Office Operations, 2nd ed., Continuum, London.

Baloglu, S. and Pekcan, Y. (2004) 'The website design and internet site marketing practices of upscale and luxury hotels in Turkey', Tourism Management, Vol. 27, No. 3, pp.171-176.

Bardi, J.A. (2007) Hotel Front Office Management, 4th ed., John Wiley \& Sons Inc, New Jersey.

Bentley, R. (2011) Click Here to Book, Caterer and Hotel Keeper, October-November, pp.38-40.

Berne, C., Garcia-Gonzalez, M. and Mugica, J. (2012) 'How ICT shifts the power balance of tourism distribution channels', Tourism Management. Vol. 33, No. 3, pp.1-10.

Buhalis, D. and Licata, M.C. (2002) 'The future eTourism intermediaries', Tourism Management, Vol. 23, No. 5, pp.207-220.

Cacia, C., Aiello, L., Singer, P. and Ferri, A. (2011) 'Internet management for communication-distribution interaction as a means to maximize customer consumption experience: the Volagratis case', Advanced Technology Management for Retailing, Vol. 8, No. 3, pp.145-179.

Carroll, B. and Siguaw, J. (2003) 'The evolution of electronic distribution: effects on hotels and intermediaries', Cornell Hotel and Restaurant Administration Quarterly, August, Vol. 23, No. 2, pp.38-50 [online] http://www.sciencedirect.com (accessed 5 December 2011).

Carter, S. and Jones-Evans, D. (2000) Enterprise and Small Business: Principles, Practice and Policy, Pearson Education Limited, England.

Castillo-Manzano, J.I. and López-Valpuesta, L. (2010) 'The decline of the traditional travel agent model', Transportation Research Part E, Vol. 46, No. 7, pp.639-649.

Chathoth, R.K. (2007) 'The impact of information technology on hotel operations, service management and transaction costs: a conceptual framework for full-service hotel firms', International Journal of Hospitality Management, Vol. 26, No. 2, pp.395-408.

Chen, H., Chiang, R. and Storey, V. (2012) 'Business intelligence and analytics: from big data to big impact', MIS Quarterly, Vol. 36, No. 4, pp.1165-1188 [online] http://www.jstor.org/ stable/41703503.

Chung, T. and Law, R. (2003) 'Developing a performance indicator for hotel websites', International Journal of Hospitality Management, Vol. 22, No. 4, pp.119-125. 
Cizmar, S. and Weber, S. (2000) 'Marketing effectiveness of the hotel industry in Croatia', International Journal of Hospitality Management, Vol. 19, No. 1, pp.227-240.

Collis, J. and Hussey, R. (2009) Business Research: A Practical Guide for Undergraduate and Postgraduate Students, 3rd ed., Palgrave Macmillan, UK.

Creswell, J.W. (2018) Research Design: Qualitative, Quantitative, and Mixed Methods Approaches Paperback, Sage, New York

Dana, L.P. and Dana, T. (2005) 'Expanding the scope of methodologies used in entrepreneurship research', International Journal of Entrepreneurship and Small Business, Vol. 2, No. 1, pp.79-88.

Dana, L.P. and Dumez, H. (2015) 'Qualitative research revisited: epistemology of a comprehensive approach', International Journal of Entrepreneurship and Small Business, Vol. 26, p.2.

Dana, L.P. and Ramadani, V. (2015) 'Context and uniqueness of family business', in Dana, L.P. and Ramadani, V. (Eds.): Family Businesses in Transition Economies Management, Succession and Internationalization, Springer, New York.

Dix, C. and Baird, C. (1998) Front Office Operations, 4th ed., Addison Wesley Longman Limited, UK.

Edinburgh Airport [online] https://www.edinburghairport.com/.

Erdogmus, I.E. and Çiçek, M. (2011) 'Online group buying: what is there for the consumers?', Procedia Social and Behavioral Sciences, Vol. 24, No. 2, pp.308-331.

Etemad, H., Wilkinson, I. and Dana, L.P. (2010) 'Internetization as the necessary condition for internationalization in the newly emerging economy', Journal of International Entrepreneurship, Vol. 8, No. 4, pp.319-342.

Forrester, M. (2008) The Internet Revolution and Your Hotel. Hospitality, Hotel and Travel News: Occupancy Marketing, June [online] http://www.4hoteliers.com/4hots_fshw.php?mwi=2978 (accessed 4 December 2011).

Gerguri-Rashiti, S., Ramadani, V., Abazi-Alilli, H., Dana, L.P. and Ratten, V. (2015) 'ICT, innovation and firm performance: the transition economies context', Thunderbird International Business Review, Vol. 59, No. 1, pp.93-102.

Getz, D. and Carlson, J. (2000) 'Characteristics and goals of family and owner-operated businesses in the rural tourism and hospitality sectors', Tourism Management, Vol. 21, No. 6, pp.547-560.

Guest Centric (2011) Top Five Items in a Hotel Digital Marketing Strategy, Hotel Marketing, December [online] http://hotelmarketing.com/index.php/content/article/top_five_items_in_a_ hotel_digital_marketing_strategy (accessed 4 December 2011).

Hassanien, A., Dale, C. and Clarke, A. (2010) Hospitality Business Development, Butterworth-Heinemann, Oxford.

Heung, V.C.S. (2003) 'Internet usage by international travelers: reasons and barriers', International Journal of Hospitality Management, Vol. 15, No. 7, pp.370-378.

Ip, C., Leung, R. and Law, R. (2011) 'Progress and development of information and communication technologies in hospitality', International Journal of Contemporary Hospitality Management, Vol. 23, No. 4, pp.533-551.

Janes, J. (2001) 'Causality', Library Hi Tech, Vol. 19, No. 2, pp.191-193.

Jobber, D. and Fahey, J. (2006) Foundations of Marketing, McGraw Hill Education, New York.

Kerin, R.A., Hartley, S.W. and Rudelius, W. (2009) Marketing: The Core, McGraw-Hill Irwin, New York.

Kim, W.G., Ma, X. and Kim, D.J. (2006) 'Determinants of Chinese hotel customers' e-satisfaction and purchase intentions', Tourism Management, Vol. 27, No. 3, pp.890-900.

Kotler, P. and Armstrong, G. (2011) Principles of Marketing, 13th ed., Pearson Education Inc, New Jersey.

Kucuk, S.U. and Krishnamurth, S. (2007) 'An analysis of consumer power on the internet', Technovation, Vol. 27, No. 4, pp.47-56. 
Law, R. and Hsu, C.H.C. (2005) 'Customers' perceptions on the importance of hotel web site dimensions and attributes', International Journal of Contemporary Hospitality Management, Vol. 17, No. 6, pp.493-503.

Litvin, S.W., Goldsmith, R.E. and Pan, B. (2008) 'Electronic word-of-mouth in hospitality and tourism management', Tourism Management, Vol. 29, No. 5, pp.458-468.

Ma, J.X., Buhalis, D. and Song, H. (2003) 'ICTs and internet adoption in China's tourism industry', International Journal of Information Management, Vol. 23, No. 1, pp.451-467.

Martin, D. (2007) 'Management learning exercise and trainer's note for building grounded theory in tourism behaviour', Journal of Business Research, Vol. 60, No. 2, pp.742-748.

Mawson, S. (2000) The Fundamentals of Hospitality Marketing, Continuum, London.

Morosan, C. and Jeong, M. (2008) 'Users' perceptions of two types of hotel reservation websites', International Journal of Hospitality Management, Vol. 27, No. 2, pp.284-292.

O'Connor, P. (2008a) 'Distribution channels and e-commerce', in Handbook of Hospitality Marketing, Elsevier, Oxford.

O'Connor, P. (2008b) 'Electronic distribution', in Handbook of Hospitality Operations in IT, Elsevier, New York [online] http://www.sciencedirect.com (accessed 5 December 2011).

O'Connor, P. and Murphy, J. (2004) 'Research on information technology in the hospitality industry', International Journal of Hospitality Management, Vol. 23, No. 2, pp.473-484.

Peters, M. and Buhalis, D. (2004) 'Family hotel businesses: strategic planning and the need for education and training', Education + Training, Vol. 46, Nos. 8/9, pp.406-415 [online] https://doi.org/10.1108/00400910410569524.

Phelan, K.V., Christodoulidou, N., Countryman, C.C. and Kistner, L.J. (2011) 'To book or not to book: the role of hotel web site heuristics', Journal of Services Marketing, Vol. 25, No. 2, pp.134-148.

Pizam, A. (2010) International Encyclopedia of Hospitality Management, 2nd ed., Butterworth-Heinemann, UK.

Ramadani, V. and Hoy, F. (2017) 'Context and uniqueness of family businesses', in Dana, L-P. and Ramadani, V. (Eds.): Family Businesses in Transition Economies, pp.9-37, Springer, Cham.

Ramadani, V., Abazi-Alili, H., Dana, L.P., Rexhepi, G. and Ibraimi, S. (2017) 'The impact of knowledge spillovers and innovation on firm-performance: findings from the Balkans countries', International Entrepreneurship and Management Journal, Vol. 13, No. 1, pp.299-325

Rong, J., Li, G. and Law, R. (2009) 'A contrast analysis of online hotel web service purchasers and browsers', International Journal of Hospitality Management, Vol. 28, No. 1, pp.466-478.

Salerno, N. (2007) Internet Age Suits Hotel Industry Well, Hotel Marketing, July [online] http://hotelmarketing.com/index.php/content/article/internet_age_suits_hotel_industry_well (accessed 4 December 2011).

Scottish Government (2015) Scotland's Economic Strategy [online] https://beta.gov.scot/publications/scotlands-economic-strategy/.

Scottish Government (2017) [online] http://www.scottishgovernment.co.uk.

Shepherd, D. and Haynie, M. (2009) ;Family business, identity conflict, and an expedited entrepreneurial process: a process of resolving identity conflict', Entrepreneurship Theory and Practice, Vol. 33, No. 6, pp.1245-1264 [online] https://doi.org/10.1111/j.15406520.2009.00344.x.

Shuai, J-J. and Wu, W-W. (2011) 'Evaluating the influence of e-marketing on hotel performance by DEA and grey entropy', Expert Systems with Applications, Vol. 38, No. 2, pp.8763-876.

Tse, A.C-B. (2003) 'Disintermediation of travel agents in the hotel industry', International Journal of Hospitality Management, Vol. 22, No. 3, pp.453-460.

Tso, A. and Law, R. (2005) 'Analysing the online pricing practices of hotels in Hong Kong', International Journal of Hospitality Management, Vol. 24, No. 1, pp.301-307. 
Veland, R., Amir, D. and Samije, A.D. (2014) 'Social media channels: the factors that influence the behavioural intention of customers', International Journal of Business and Globalisation, Vol. 12, No. 3 [online] https://doi.org/10.1504/IJBG.2014.060214.

Visit Scotland (2005) The Tourism Perspective: Investment for Growth [online] http://www.visitscotlandannualreview.com/content/pdfs/tour_prosp (accessed 1 April 2012).

Walters, C.G. (1977) Marketing Channels, Goodyear Publishing Company Inc, California.

Wang, H-Y. and Wang, S-H. (2009) 'Predicting mobile hotel reservation adoption: insight from a perceived value stand point', International Journal of Hospitality Management, Vol. 29, No. 3, pp.598-608.

Wang, Y. and Qualls, W. (2007) 'Towards a theoretical model of technology adoption in hospitality organizations', International Journal of Hospitality Management, Vol. 26, No. 1, pp.560-573.

Williams, A. (2006) 'Tourism and hospitality marketing: fantasy, feeling and fun', International Journal of Contemporary Hospitality Management, Vol. 18, No. 6, pp.482-495.

Wong, J. and Law, R. (2005) 'Analysing the intention to purchase on hotel websites: a study of travellers to Hong Kong', International Journal of Hospitality Management, Vol. 24, No. 2, pp.311-329.

$\mathrm{Wu}, \mathrm{S}-\mathrm{I} ., \mathrm{Wei}, \mathrm{P}-\mathrm{L}$. and Chen, J-H. (2008) 'Influential factors and relational structure of internet banner advertising in the tourism industry', Tourism Management, Vol. 29, No. 1, pp.221-236.

Zikmund, W. (1997) Business Research Methods, 5th ed., Harcourt Brace College Publishers, USA. 